\title{
THE EFFECT OF USING RIDDLE TECHNIQUE ON STUDENTS' VOCABULARY MASTERY OF THE 2017/2018 TENTH GRADE STUDENTS OF SMK SWASTA PEMDA LANGKAT BAHOROK
}

\author{
Lusiana, Eka Rahmadanta Sitepu \\ Department of English Language Education, College of Budidaya Binjai
}

\begin{abstract}
Learning mthod innovation will influence learning media used and it is hoped to improve learning qualities. This study was intended to find out The Effect of Using Riddle Technique on Students' Vocabulary Mastery of The 2017/2018 Tenth Grade Students of Smk Swasta Pemda Langkat Bahorok Kabupaten Langkat. There were two classes for the population with the total 56 students. And for the sample, all population were taken out. The data were collected by administering tests. The data was applied statistically. Then the data were analyzed by applying the calculation of test. Havinf the data been computed by using t-test formula, it shows that $\mathrm{t}_{\text {observed }}$ in certain degree

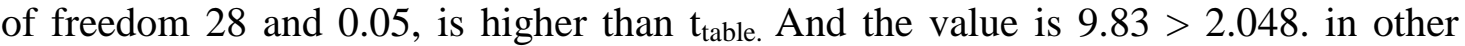
words, the hypothesis "there is any Effect of Using Riddle Technique on Students' Vocabulary Mastery of The 2017/2018 Tenth Grade Students of Smk Swasta Pemda Langkat Bahorok Kabupaten Langkat, is accepted. Learning method with interactive technique can improve students' vocabulary, because if the method can interest students' attention they will enjoy and easy to receive the lesson.
\end{abstract}

Keywords : Riddle and Vocabulary

\section{INTRODUCTION}

Vocabulary is the total number of words which make up a language. In this study the writer took riddle as a technique to improve the student' vocabulary. It is express that language is arranged by so many words and phrases. So vocabulary is a collection of words or phrases in language. It means that vocabulary is a component of language which gives information or explanation in a language terms. The other definition, "Vocabulary is one of the most significant aspect of language development". And "Vocabulary is a list or set of words for a particular language or a list or set of word that individual speakers of language might use" ${ }^{2}$. In our life we always use vocabulary to communicate. Based on these statements, vocabulary is a

${ }^{1}$ David L. Stepherd. Vocabulary Meaning and Word Analysis, Comprehension High School Reading Methods. (USA : Bell and Howel Company, Co, 1971)p.39

${ }^{2}$ Evelyn Hatch and Cheryl Brown, Vocabulary, Semantic and Language Education,

(Cambridge: Cambridge University Press, 1995), p. 1 
word or sound which represents a certain meaning as an utterance unity. It is the most important part of language. It is clear that vocabulary is a fundamental of language. There is no language without vocabulary. According to those statements can be concluded that vocabulary is a number of words that is known by individuals in a certain language, including English. In line with this idea, can be said that vocabulary is one of major elements of language because it covers words in which it will enable the people to communicate with others.

Vocabulary plays an important role because it appears in every language skills. "Vocabulary is the most importance of language, students who rich in vocabulary will be successful both in expression skills : speaking and writing, and receptive skills : listening and reading, but who low in vocabulary will get trouble in those skills" Vocabulary building is really important in any language learning. Vocabulary is a necessary ingredient for all communication. Language learners encounter vocabulary on a daily basis, and must be able to acquire and retain it. As a language teacher, one of your main tasks is to help students develop a rich and useful vocabulary inventory. "Words seem to be a basic level category in language learning"4. Based on the statements, can be conclude that vocabulary is the basic knowledge to be smart in language. Vocabulary is the most important factor in the teaching learning of English as a foreign language even in all language.

To improve the students' vocabulary the writer use a funny technique that is riddle. There are many definitions of riddle "Riddle is the nouns all refer to something baffling or confusing which is to be solved"5. "Word riddle" is questions with pun-like responses"6. "A riddle is a statement or question or phrase having a double or veiled meaning, put forth as a puzzle to be solved"7 . The term "riddle" ( as a noun ) according to Longman Dictionary of the English language is defined as a question, problem or

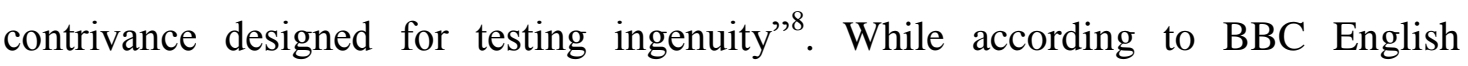
Dictionary, "riddle is a question, game or toy which you have to think about carefully

\footnotetext{
${ }^{3}$ Lee C. Deighton. Encyclopedia of Education. (New York : Mc. Millan Co Free Press, 1971) p. 461

${ }^{4}$ Angga Ratih Sapta Rini. The Effect of Using Riddles on Vocabulary Achievement. (Thesis Situbondo, Jember University, 2011) p. 8

${ }^{5}$ Bergen Evans, Cornelia Evans, A Dictionary Of Contemporary American Usage. (,New York, Random House, Inc, 1957)

6 Danny Brassell, Leena Furtado,. Enhancing English As A Second Language Students' Vocabulary. (The Reading Matrix, 2008) Vol. 8, No. 1

${ }^{7}$ Ibid, (2008) p. 1

${ }^{8}$ Longman English Dictionary. Longman : Longman University Press, 2004) p. 204
} 
in order to answer it correctly or put it together properly"9. It is clear that riddle is interesting to be done. People are eager to do them and they may take a position of increasing importance now days.

Based on that statement, the writer conclude that riddle itself is the nouns which it can be said clues for something, and the statement or question or phrase which have a double meaning. And riddles can be one of the effective technique in teaching language, because in riddle game require ingenuity to solving the question or problem. So it can make students more training their brain, with it students can be more motivated to learn vocabulary.

The Examples of Riddle

\begin{tabular}{|c|l|l|}
\hline No & \multicolumn{1}{|c|}{ Question } & \multicolumn{1}{|c|}{ Answer } \\
\hline 1 & $\begin{array}{l}\text { What do you see twice in a week, once in a year, but } \\
\text { never in a day? }\end{array}$ & The letter "e" \\
\hline 2 & $\begin{array}{l}\text { When the drops start to fall, I come in handy. My } \\
\text { waterproof top is really quite dandy. }\end{array}$ & Umbrella \\
\hline 3 & What has just two words but thousands of letters ? & A post office \\
\hline 4 & Where does Friday come before Thursday ? & In a dictionary \\
\hline 5 & $\begin{array}{l}\text { Thirty men and only two women, but they hold the } \\
\text { most power. Dressed in black and white, they could } \\
\text { fight for hours. Who are they? }\end{array}$ & Chess pieces \\
\hline
\end{tabular}

\section{The Benefits of Riddle Technique}

There are some benefits of using riddle technique to improve students' vocabulary. They are : (1) Can introduce the students to intellectual humor. Laughter is important to happiness and health. In addition, laughter is a really good way to motivate people to continue working after a long monotonous day. It can relax the brain and body, helps us release stress, and makes us feel great. Boredom and keeping students' attention is one of the largest problems associated with education today, so riddle can be a great way to break up the day and relax the brain, while keeping the brain working. (2) Work their brains, problem solving and critical thinking skills are two of the most important and sought after abilities in society today. This is demonstrated by the importance of standardized testing when getting into college and

\footnotetext{
${ }^{9}$ BBC Dictionary. London : BBC Corp., 2002) p. 936
} 
graduate school. Both the ACT and SAT are heavily based on critical thinking and problem solving skills. Riddles have been shown to improve students' comprehension and activity, making them the perfect prep for children. (3) Reading Comprehension, everybody can read to some extent, but this doesn't mean that they can read quickly enough or understand difficult content that will enable them to be useful in the workforce. Riddles can help out with this by expanding vocabulary and increasing the ability to understand context. (4) Expand their vocabulary, when everyone encounters words that they don't understand they figure them out through context. Riddles give words a great deal of context which makes it easier for students to learn, remember and use these words. In another way, riddles force kids to ask more questions about words they don't understand. (5) Giving them the opportunity to teach, teaching students riddle allows them to know and understand something that most other people do not, giving them an opportunity to repeat them and teach them to others. When the students it's very different from most of what they learn, they can teach these riddles to their peers, parents, and teachers. This reinforces their understanding of the riddle and it also allow them to interact with people in a constructive social way.

2. Using Riddle Technique to Improve Students' Vocabulary

Through riddle plays teacher is available to provide assistance if require, making correction and offering extra clues. Accordingly, the students are encouraged to make their own riddle plays along similar lines. The researcher proposes the procedure in relation to teaching vocabulary through riddle as follow:

1. The researcher who acts as teacher prepares the students to learn in the class.

2. Teacher tells and explains the lesson about. For example about profession. Because the researcher take the language feature of descriptive text that is about noun.

3. Teacher explains the rules of riddle technique to be practiced as clearly possible so that all students may understand and familiar. The rules are :

a. Students are divided into two groups.

b. Then every group write many words about profession

c. After that one by one of the member write it in the white board.

d. Then the other group answers the word. If s/he can do the challenge, so s/he gets the score and changes give the challenge. But if s/he fail, so won't get score and will be punished. the challenge is : 
From the word that given by member of group, one member of the other group removes the letter from the word, but still remains English and has meaning.

For example:

\section{TEACHER}

$\begin{array}{lll}\text { Remove the letter ER } & \text { TEACH } & \text { : Mengajar } \\ \text { Remove the letter TEAC } & \text { HER } & \text { : Dia (Kepemilikan) } \\ \text { Remove the letter CHER } & \text { TEA } & \text { : Teh } \\ \text { Remove the letter TER } & \text { EACH } & \text { : Masing-masing. }\end{array}$

The other example :

\section{STARTLING}

$\begin{array}{lcl}\text { Remove the letter L } & \text { STARTING } & \text { : Mengejutkan } \\ \text { Remove the letter T } & \text { STARING } & \text { : Menatap } \\ \text { Remove the letter A } & \text { STRING } & \text { : Tali } \\ \text { Remove the letter R } & \text { STING } & \text { : Sengatan } \\ \text { Remove the letter T } & \text { SING } & \text { : Bernyanyi } \\ \text { Remove the letter G } & \text { SIN } & \text { : Dosa } \\ \text { Remove the letter S } & \text { IN } & \text { : Di Dalam } \\ \text { Remove the letter N } & \text { I } & : \text { Saya }\end{array}$

\section{METHODOLOGY}

This study was conducted at SMK Swasta Pemda Langkat Bahorok, located at Jl. Perintis Kemerdekaan. This study was a quasi experimental research. This research used two classes. The first class treated as the experimental class and the second class was as the control class. In this research, the experimental class received the treatment that it was taught vocabulary by using riddles. While the control didn't receive any treatment which means the teacher in this class though vocabulary by using common techniques used by the English teacher in that school. There were 28 students as experimental class by applying riddle technique. And 28 students as control class by applying traditional technique. The effect of riddle was measured by comparing pretest and post-test. The tests were complete sentence as pre-test and guess words as post-test in experimental class. While in control class only test based on their handbook. In experimental class, if post-test was higher than pre-test, riddle technique 
was called success and effective to improve students' vocabulary. To know the result the writer use formula $t_{\text {table. }}$

\section{RESULT AND DATA ANALYSIS}

The data of this research was found by using experimental and control group. This research was conducted in two classes with 68 students. Pretest, treatment, and posttest are applied to take the data. It took four times meeting with the students (sample) with a pretest, a pre-requirement test, a post test, and two days treatment. The result of the study shows that the students are more motivate and have achievement in vocabulary mastery especially taught by using riddle technique.

All of the data can be seen below :

Calculation of Experimental Class

\begin{tabular}{|c|c|c|c|}
\hline No & Students & Pre-Test & Post-Test \\
\hline 1 & EC 1 & 70 & 85 \\
\hline 2 & EC 2 & 65 & 80 \\
\hline 3 & EC 3 & 59 & 75 \\
\hline 4 & EC 4 & 65 & 80 \\
\hline 5 & EC 5 & 59 & 75 \\
\hline 6 & EC 6 & 65 & 85 \\
\hline 7 & EC 7 & 65 & 80 \\
\hline 8 & EC 8 & 65 & 85 \\
\hline 9 & EC 9 & 75 & 85 \\
\hline 10 & EC 10 & 70 & 80 \\
\hline 11 & EC 11 & 60 & 70 \\
\hline 12 & EC 12 & 65 & 80 \\
\hline 13 & EC 13 & 60 & 75 \\
\hline 14 & EC 14 & 60 & 75 \\
\hline 15 & EC 15 & 63 & 75 \\
\hline 16 & EC 16 & 75 & 85 \\
\hline 17 & EC 17 & 65 & 75 \\
\hline 18 & EC 18 & 70 & 80 \\
\hline 19 & EC 19 & 65 & 80 \\
\hline
\end{tabular}




\begin{tabular}{|c|c|c|c|}
\hline 20 & EC 20 & 77 & 85 \\
\hline 21 & EC 21 & 65 & 85 \\
\hline 22 & EC 22 20 & 85 \\
\hline 23 & EC 23 & 59 & 80 \\
\hline 24 & EC 24 & 65 & 85 \\
\hline 25 & EC 25 & 70 & 80 \\
\hline 26 & EC 26 & 67 & 80 \\
\hline 27 & EC 27 & 70 & 85 \\
\hline 28 & EC 18 & 67 & $\mathbf{2 2 2 5}$ \\
\hline
\end{tabular}

Calculation of Control Class

\begin{tabular}{|c|c|c|c|}
\hline No & Students & Pre-Test & Post-Test \\
\hline 1 & $\mathrm{CC} 1$ & 70 & 75 \\
\hline 2 & $\mathrm{CC} 2$ & 65 & 70 \\
\hline 3 & CC 3 & 59 & 70 \\
\hline 4 & $\mathrm{CC} 4$ & 65 & 70 \\
\hline 5 & CC 5 & 59 & 69 \\
\hline 6 & CC 6 & 65 & 75 \\
\hline 7 & CC 7 & 65 & 75 \\
\hline 8 & CC 8 & 65 & 70 \\
\hline 9 & CC 9 & 75 & 75 \\
\hline 10 & CC 10 & 70 & 75 \\
\hline 11 & $\mathrm{CC} 11$ & 60 & 70 \\
\hline 12 & $\mathrm{CC} 12$ & 65 & 70 \\
\hline 13 & CC 13 & 60 & 70 \\
\hline 14 & CC 14 & 60 & 70 \\
\hline 15 & CC 15 & 63 & 70 \\
\hline 16 & CC 16 & 75 & 80 \\
\hline 17 & CC 17 & 65 & 75 \\
\hline 18 & CC 18 & 70 & 80 \\
\hline 19 & CC 19 & 65 & 75 \\
\hline
\end{tabular}




\begin{tabular}{|c|c|c|c|}
\hline 20 & CC 20 & 77 & 80 \\
\hline 21 & CC 21 & 65 & 75 \\
\hline 22 & CC 22 & 70 & 80 \\
\hline 23 & CC 23 & 59 & 75 \\
\hline 24 & CC 24 & 65 & 75 \\
\hline 25 & CC 25 & 70 & 75 \\
\hline 26 & CC 26 & 67 & 75 \\
\hline 27 & CC 27 & 70 & 75 \\
\hline 28 & CC 28 & 67 & 70 \\
\hline \multicolumn{2}{|c}{ Total } & $\mathbf{1 8 5 1}$ & $\mathbf{2 0 6 4}$ \\
\hline
\end{tabular}

The Result of Calculation

\begin{tabular}{|c|c|c|}
\hline DATA & Experimental Class $\left(\mathbf{X}_{\mathbf{1}}\right)$ & Control Class $\left(\mathbf{X}_{\mathbf{2}}\right)$ \\
\hline$\sum x a$ & 1851 & 1851 \\
\hline$\sum x b$ & 2225 & 2064 \\
\hline$\sum\left(Y_{1}\right)^{2}$ & 176.665 & 152.116 \\
\hline $\mathrm{SD}$ & 8.74 & 8.58 \\
\hline$\overline{X_{a}}$ & 66.1 & 66.1 \\
\hline$\overline{X_{b}}$ & 79.4 & 73.7 \\
\hline
\end{tabular}

To prove the hypothesis the writer analyzed the data by applying the t-test formula :

$$
t=\frac{M A+M B}{\sqrt{\left(\frac{X A^{2}+X B^{2}}{n A-n B+2}\right)\left\{\frac{1}{n A}+\frac{1}{n B}\right\}}}
$$

$\mathrm{MA}=79.4$

$\mathrm{MB}=73.7$

$\mathrm{XA}=8.74$

$\mathrm{XA}=8.58$

$\mathrm{NA}=28$

$\mathrm{NB}=28$ 
$t=\frac{79.4+737}{\sqrt{\left(\frac{8.74+8.58}{28-28+2}\right)\left\{\frac{1}{28}+\frac{1}{30}\right\}}}$

$t=\frac{153.1}{\sqrt{\left(\frac{17.32}{2}\right)\{28\}}}$

$t=\frac{153.1}{\sqrt{(8.66)\{28\}}}$

$t=\frac{153.1}{\sqrt{242.48}}$

$t=\frac{153.1}{15.57}$

$t=9.83$

The basic for testing the hypothesis is as follows $\mathrm{H}_{\mathrm{a}}$ is accepted if the $\mathrm{t}$ observed > t-table. Where critical value for degree of freedom (df) 28 at level of significant 0.05 is 2.048 .

The result of computing the t-test shows that the t-observed is larger than t-table or it can be seen as follows :

t-obs $>$ t-table (0.05) with df 28

$9.83>2.048$ (0.05) with df 28

\section{DISCUSSION AND CONCLUSION}

Many technique to teaching English vocabulary, one of them is using riddle. Beside can increase the students' vocabularies and make the students be interested to learn English, it also make the students to think deeply and focus to solve the problem. So the students can make habit to exercise their thinking. Most of the students like games in process of teaching and learning, and it affect the situation in the class become funny and interested. Although sometimes the students only play and not serious but if the teacher can get the students' focus and attention so this technique will be fun and benefit.

After finishing the work data collecting and calculation, the researcher is now drawing some conclusion of his works as follows :

Based on the data analysis, it is concluded that the students' achievement of vocabulary by taught riddle technique is different than the student's achievement of vocabulary by taught conventional technique. By using riddle, the students can learn 
and retain words more easily. In other word, it can help the students to improve their interesting and challenging. It encourages them to cooperate well.

By the final result of the research is found by the researcher which $t_{\text {observed }}$ is 9.83. And $t_{\text {table }}$ in degree of freedom 0.05 is 2.048. It shows that $t_{\text {observed }}$ is higher than

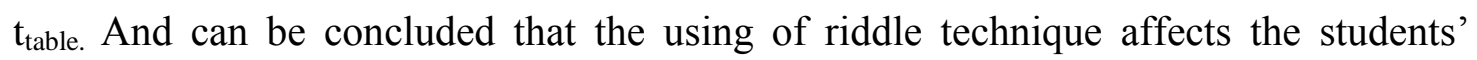
vocabulary mastery.

\section{REFERENCES}

Angga Ratih Sapta Rini. The Effect of Using Riddles on Vocabulary Achievement. Thesis Situbondo, JEMBER UNIVERSITY. 2011.

BBC Dictionary. London : BBC Corp. 2002.

Bergen Evans, Cornelia Evans, A Dictionary Of Contemporary American Usage. New York, Random House, Inc. 1957.

Danny Brassell, Leena Furtado,. Enhancing English As A Second Language Students' Vocabulary. The Reading Matrix, 2008) Vol. 8, No. 1

David L. Stepherd. Vocabulary Meaning and Word Analysis, Comprehension High School Reading Methods. USA : Bell and Howel Company, Co. 1973.

Evelyn Hatch and Cheryl Brown, Vocabulary, Semantic and Language Education, Cambridge: Cambridge University Press. 1995.

Lee C. Deighton. Encyclopedia of Education.. New York : Mc. Millan Co Free Press. 1971.

Longman English Dictionary. Longman : Longman University Press, 2004.

Sugiyono. MetodePenelitian. Bandung : Alfabeta. 2009. 